\title{
Pohlia section Apalodictyon (Bryaceae, Bryophyta) in Central and South America
}

\author{
Guillermo M. Suárez ${ }^{* 1}$ \& María M. Schiavone ${ }^{2}$ \\ 1 CONICET, Fundación Miguel Lillo, Miguel Lillo 251, (4000) San Miguel de Tucumán, \\ Tucumán, Argentina; suarezgm@csnat.unt.edu.ar; \\ 2 Facultad de Ciencias Naturales e I.M.L., Miguel Lillo 205, (4000) San Miguel de \\ Tucumán, Tucumán, Argentina.
}

With 4 figures and 2 maps

Suárez, G.M. \& M.M. Schiavone (2010): Pohlia section Apalodictyon (Bryaceae, Bryophyta) in Central and South America. - Nova Hedwigia 91: 377-388.

\begin{abstract}
Pohlia section Apalodictyon is taxonomically studied for Central and South America. Three species are recognized in the study area (Pohlia lonchochaete, P. magnifica and $P$. wahlenbergii). Mniobryum bolivianum from Bolivia is proposed as a new synonym of $P$. wahlenbergii. Three new lectotypes are designated. We provide the first illustrations of $P$. lonchochaete and $P$. magnifica, two neglected species from southern South America and describe and illustrate all species observed. Distribution maps of the taxa in Latin America are presented.
\end{abstract}

\section{Introduction}

Bryum Hedw. section Apalodictyon Müll.Hal. was erected by C.Müller (1848) to include 33 species, of which B. carneum With. and B. albicans (Wahlenb.) Röhl. were later transferred by Limpricht (1892) to Mniobryum Limpr. He characterized Mniobryum based on sporophytic characters, while the gametophytes were the same as those defined for Pohlia Hedw. (elimbate leaves, elongate to fusiform cells and costa percurrent). Since then, Mniobryum has been reduced to a subgenus (Amann 1893), while recognized by others (Brotherus 1903, 1924).

Shaw (1982) revised Mniobryum species from North America, Central America and the West Indies. He placed the genus and the species involved within Pohlia. In turn, Nyholm (1958) and Shaw (1981) used the name Mniobryum for a section of Pohlia. Ochyra et al. (2008) noted that Mniobryum corresponds to a name not validly published according to the International Code of Botanical Nomenclature and is a later name than Apalodictyon. 